\title{
The Use of Environmental Taxation Instruments in Order to Ensure Sustainable Development of Mining Region
}

\author{
Tatiana Tyuleneva ${ }^{1}$, Marat Moldazhanov ${ }^{2}$ \\ ${ }^{1}$ T.F. Gorbachev Kuzbass State Technical University, Department of Management Accounting and \\ Analysis, 650000 Kemerovo, 28 Vesennya st., Russian Federation \\ ${ }^{2}$ Kazakh Humanitarian-Law Innovative University, Department of Finance and Accounting, 11 \\ Mangilic st., Semey, East Kazakhstan region, 071400, Republic of Kazakhstan
}

\begin{abstract}
One of the problems of mineral resource clusters` sustainable development is the creation of an economic mechanism for environmental management that ensures compliance with the principles of rational resource consumption through the creation of environmental taxation tools. The article describes trends in implementation of sustainable development through environmental taxation: environmental taxes, promotion of rational use of natural resources, application of environmental technologies, support the use of alternative sources of energy, including through the organization of trading quotas on emissions into the environment, and their applicability in Russian Federation and the mining region is evaluated. In addition, a comparative analysis of the dynamics of relative indicators of production activity, negative impact on the environment and costs to eliminate it, carried out in Kemerovo region, and justified the need to use environmental taxation tools to ensure sustainable development of the region.
\end{abstract}

\section{Introduction}

Using the resource potential of a mining region significantly affects the dynamics of its socio-economic development. However, this impact can be either positive or negative. For a long time, the development of natural resources was carried out using a consumer approach without taking into account the social needs of the population. Today the previously existing point of view is being reformed, and the position of ensuring conditions for the sustainable development of resource regions is increasingly recognized [1]. In order to eliminate past and minimize future negative consequences of natural resource development and ensure future welfare growth, there is a need to develop principles of environmental management based on the implementation of sustainable development goals. There is a need for a transition to sustainable development that provides a balanced solution to socio-economic problems and problems of preserving a favorable environment and natural resource potential in order to meet the needs of present and future generations.

One of the main conditions for ensuring sustainable development of the mining region is the creation of an economic mechanism for nature management, which follows the principles of rational use of natural resources and provides the necessary reserve for 
sustainable socio-economic development in the distant future [2]. The formation of this mechanism is through the creation of instruments of environmental taxation that performs the following functions: create a financial basis decent conditions of life for present and future generations; ensure the rational use of natural resources; vehicle financial elements of the reproduction of the mineral resource base; to create prerequisites for sustainable economic development in the case of depletion of the main part of non-renewable resources.

The study of these issues is relevant for Kemerovo region as the leading mining region of Russia, the main supplier of coal for the domestic market and the second largest exporter of this type of resource.

\section{Theory of Experimental Research}

In Russian Federation most elements of resource payment taxation are enshrined in Federal legislation and practically do not involve incentives for rational use of natural resources. For this reason the legislative bodies of the mining region do not have levers of influence on local environmental users through the taxation system, and the main share of environmental payments goes to the Federal budget [3].

Thus, Kemerovo region has a large natural resource potential, and its economy is largely focused on raw materials. However a comparative analysis of the growth rates of production activity indicators, its negative impact on the environment and costs of elimination for 2014-2018 (table 1) showed the inefficiency of the applied methods of environmental management of this mining region from the point of view of implementing the sustainable development goals.

Table 1. Comparative analysis of the growth rates of production activity indicators, its negative impact on the environment and elimination costs carried out in the Kemerovo region - Kuzbass, \%.

\begin{tabular}{|l|c|c|c|c|}
\hline \multirow{2}{*}{ Indicators } & \multicolumn{4}{c|}{ Periods } \\
\cline { 2 - 5 } & $\mathbf{2 0 1 4 - 2 0 1 5}$ & $\mathbf{2 0 1 5}-\mathbf{2 0 1 6}$ & $\mathbf{2 0 1 6 - 2 0 1 7}$ & $\mathbf{2 0 1 7 - 2 0 1 8}$ \\
\hline 1. Discharge of polluted waste water & -3.4 & -3.9 & -2.5 & -18.0 \\
\hline 2. Emissions to air & +0.9 & +0.4 & +10.3 & -7.0 \\
\hline 3. Violation of land & -80.6 & +250.0 & +114.3 & +4.4 \\
\hline 4. Waste formation & +1.3 & +74.0 & -11.2 & -39.3 \\
\hline $\begin{array}{l}\text { 5. Investments in fixed assets for environmental } \\
\text { purposes - total }\end{array}$ & -27.4 & -18.9 & +88.7 & -6.2 \\
\hline 6. Investments in water protection & -45.4 & +13.4 & +111.1 & -30.4 \\
\hline 7. Investment in air protection & -50.1 & -34.7 & +75.0 & +51.8 \\
\hline 8. Investment in land protection & +3614.3 & -76.2 & -53.0 & +659.0 \\
\hline $\begin{array}{l}\text { 9. Costs of environmental protection measures } \\
\text { - total }\end{array}$ & -32.9 & +5.7 & +33.6 & +12.9 \\
\hline 10. Costs of air protection & -40.7 & +10.1 & +71.0 & +23.1 \\
\hline 11. Costs of protecting water & -33.3 & +21.1 & +17.7 & +8.1 \\
\hline 12. Costs of waste disposal & -21.2 & -49.5 & +38.9 & +12.8 \\
\hline 13. Gross regional product - total & +12.1 & +2.6 & +22.3 & +17.3 \\
\hline 14. Gross regional product - mining & +34.7 & +18.0 & +50.8 & +18.1 \\
\hline $\begin{array}{l}\text { 15. Share of environmental protection } \\
\text { expenditures in gross regional product }\end{array}$ & -40.2 & +3.0 & +9.2 & -3.7 \\
\hline
\end{tabular}

In 2015, despite a slight increase in emissions (0.9\%) in comparison with increase of gross regional product in the whole region $(12.1 \%)$ and mining sector $(34.7 \%)$, and reducing the discharge of pollutants into water bodies $3.4 \%$ and reduction in use of disturbed lands for $80.6 \%$, we had significant decrease in investment in fixed capital for 
environmental purposes (27.4\%) and expenses for environmental activities (32.9\%), accompanied by a reduction in their share in gross regional product by $40 \%$. In terms of investment the largest reduction was observed for investments in air protection (50\%), and for expenditures on water protection $(33 \%)$.

In 2016 there was a more favorable dynamics of comparable indicators compared to the previous period. Thus, there was an increase in the share of expenditures on environmental protection in the gross regional product by $3 \%$, as well as an increase in investment in fixed assets and expenditures on water protection by 13 and $21 \%$, respectively, which exceeds the growth of the gross regional product by 10 and 18 percentage points, and a decrease in the volume of discharges of polluted wastewater by $3.9 \%$. However there was a decrease in capital investment for air protection by more than $30 \%$ and waste disposal costs 2 times amid rising emissions and increase waste by $74 \%$, and a significant increase in disturbed lands (in 3.5 times) on the background of decline as investment in fixed capital and waste disposal costs by 76 and $50 \%$, respectively.

Significant improvements in the ratio of most comparable indicators occurred in 2017, which resulted in an increase in the share of environmental protection expenditures in the gross regional product by $9 \%$, as well as an increase in the growth rate of fixed capital investment and air protection costs over the growth rate of the gross regional product by 53 and 49 percentage points, respectively, and in the gross regional product of the mining industry by 25 and 21 percentage points, respectively. Also positive is the continued decrease in the volume of wastewater discharges by $2.5 \%$ and a decrease in waste generation by $11.2 \%$, with an increase in investment in fixed assets for water protection by more than 2 times and waste disposal costs by almost $40 \%$. However an extremely unfavorable moment of this period is a significant increase in disturbed land (more than 2 times) with a more than twofold reduction in the corresponding investment in fixed assets to eliminate this negative impact.

In 2018 the increase in expenditures on environmental protection measures, including water protection and waste disposal, was insufficient in comparison with the increase in the gross regional product both for the region as a whole and for the mining industry, which caused a decrease in the share of total environmental costs in the gross regional product by $3.7 \%$. Favorable changes were noted in relation to the increase of investments in fixed capital for land protection (in 7.6 times) and the protection of air (1.5 times) and the cost of environmental measures for all key occurred despite the reduction of discharges of polluted wastewater by $18 \%$, air emissions by $7 \%$ and the slowing growth rate of disturbed land. At the same time, a negative aspect of the region's environmental activities in 2018 was a reduction in investment in fixed assets for water protection.

Thus, the results of the analysis indicate some improvement in environmental protection in the region in terms of reducing environmental damage. However the volume of investment in environmental protection and financing of environmental measures is unstable and often insufficient compared to the volume of industrial production and negative impact on the environment of the region. This circumstance makes it necessary to use additional measures to ensure sustainable development of the region, which are proposed to use environmental taxation tools.

\section{Results and Discussion}

The study of tax payments structure showed that the current system of environmental taxes does not comply with the principles of mining region's sustainable development. First of all, this is due to the applicable procedure for collecting these payments, the main place among which belongs to the mining region's mineral extraction tax. The current procedure for calculating and paying this tax does not make the subsoil user dependent on the degree 
of negative impact on the environment, but assumes its calculation based on the estimated cost and volume of extracted minerals. At the same time, the share of this tax in the structure of tax payments in Kemerovo region in 2018 and 2019 did not exceed $2 \%$.

In this regard, it seems appropriate to analyze the tools used for environmental taxation in the world practice to implement the goals of sustainable development, as well as to assess their applicability for the mining region.

First, the use of environmental taxes. The generally accepted way to limit the increase in negative impact on the environment using economic instruments is the application of environmental taxes (fees), with the establishment of the amount of pollutants as the object of taxation [4]. Such regulators are used by tax systems of OECD member countries. The principle of environmental regulation "polluter pays" became the basis of the environmental policy of the former Soviet States [5].

The main principle of implementing this system of economic regulation is their combination with a set of emission and discharge limits, as well as waste disposal. Within these limits, basic rates are applied, and higher rates are applied for excessive environmental pollution. This distribution of rates contributes to the progressive taxation of the organizations - objects of negative impact, and the increase in rates by its economic nature corresponds to the system of environmental sanctions. In Russia this direction was implemented by setting a fee for negative environmental impact, which is supposed to be converted into an object of tax administration, which will strengthen control over the completeness of payment and replenish the source of budget revenue used to finance the costs of environmental measures.

Despite the noted prevalence of this tool, its use is associated with a number of risks. First of all, the weight of environmental taxes is of key importance. In order for them to really motivate to reduce the negative impact, these payments must be sufficiently tangible for the payers, but at the same time comparable to the costs of environmental measures. Also the disadvantages of implementing this tool include the desire to legally expand the list of harmful substances - objects of taxation, which leads, on the one hand, to an excessive increase in the cost of monitoring, control and administration, and on the other does not allow to ensure the completeness of tax revenues.

Secondly, the promotion of rational consumption of natural resources through tax incentives. The implementation of this direction involves the use of environmental payments, which are included in the cost of the extracted resource and reimbursed by the consumer in its price [6]. This includes, first of all, mineral extraction taxes, taxes on using water resources, etc., which are represented in the tax systems of almost all countries. At the same time, each of them sets its own peculiarities in forming the list of taxable objects and tax rates [7]. In the conditions of the mining region, this direction can be implemented in relation to taxpayers who have experience in the market and developed economic ties with suppliers.

Third, encouraging taxpayers to use environmental technologies in their production activities, which is primarily due to the need to reduce the anthropogenic burden on the environment. The most popular tax instruments are the exemption of certain economic entities from paying taxes, the use of accelerated depreciation of investment property for environmental purposes, as well as support for financing environmental measures through the use of tax discounts and tax credit [8].

The most radical method of preferential treatment of economic entities in the field of energy-saving technologies is the experience of France in the form of exemption from paying corporate income tax. The main form of accelerated depreciation of environmental investment property is the use of increased depreciation rates and methods of preliminary or free depreciation. Tax discounts in order to implement the principles of environmental taxation, in particular, can be applied to reduce the object of taxation for corporate income 
tax on capital investments for environmental purposes [9]. Much less often (in the practice of European taxation, it is used only by Spain), an environmental investment tax credit is applied in the form of a $10 \%$ reduction in the rate on a loan for the purchase of equipment related to environmental protection during the 10 years of its validity.

In a mining region this environmental taxation tool can be effective if the taxpayer has sufficient financial resources to purchase the appropriate equipment, technology, or patent for its use.

Fourthly, support for the use of alternative energy sources through incentives for specific excise rates and environmental taxes on products. These benefits encourage the use of renewable energy sources as an alternative to traditional mineral hydrocarbons by reducing the price of their consumption [10].

These options have been implemented in the tax systems of European countries by using reduced rates on biofuels or full withdrawal of this resource, as well as electricity generated from solar, wind, tidal, biomass or garbage, geothermal energy from taxation. Another important method of tax incentives for the use of alternative energy sources is to encourage the use of renewable energy sources in the home through the taxation system.

In addition to alternative instruments of environmental taxation used in European countries, it is advisable to review the current taxation mechanism. Environmental management is directly related to environmental protection. In this regard, from the point of view of greening taxation, the quotas for environmental emissions and pollution limits applied in the US can be considered. It is based on the principle of creating a market for rights to negative burdens that represent losses or benefits to third parties, based on the premise that the rights to natural resources belong to the entire society. Environmental supervision bodies set the volume of environmental pollutants per year, provided that the quality of water resources, air and soil is maintained at the level of standards. After that, a fixed number of rights with the size of 1 ton of polluting substance each are put up for auction. The total supply of emission quotas remains fixed, so if the cost is high, environmentally harmful economic entities will be forced to reduce the amount of negative impact through the introduction of environmental measures or the use of environmental technologies and materials. As a result, an equilibrium market price is formed for each right to have a negative impact on the environment.

Despite the undoubted advantage of using this environmental tax tool to stimulate environmental activities, its use in a mining region and a commodity-oriented economy may require the acquisition of carbon rights in addition to the main export goods, which, if the price of hydrocarbons increases, may create a restriction on trade in energy-intensive products in Russia.

\section{Conclusion}

Different types of environmental taxation instruments should be used for the sustainable development of the region where there is a negative impact on the environment. Since natural resources belong to society as a whole, it is perfectly fair to use in the public interest the income from their provision for use in order to finance environmental activities and reproduction of resources.

The current system of environmental taxation does not meet the goals of sustainable development of the resource region. Further steps to reform the tax system should be taken in the direction of adjusting the composition and structure of resource payments, increasing their importance in the formation of state revenues. It is also necessary to clarify the mechanism for taxation of non-renewable resources in accordance with rental taxation principles. Since the issues of development and exploitation of natural objects are the subject of regional regulation, first of all, mining regions should solve the problems of 
natural resources renewal and reproduction, as well as overcoming the adverse consequences of the development and exploitation of natural objects. At the same time the use of environmental taxation tools should be carried out with priority to the interests of sustainable development and preserving the financial stability of economic entities-subsoil users of the mining region.

\section{References}

1. G. Semenova, E3S Web of Conferences, 105, 04011 (2019)

2. T. Tyuleneva, Coal in the $21 \mathrm{st}$ Century: Mining, Intelligent Equipment and Environment Protection conference proceedings, 1, 68 (2018)

3. E. Shuvalova, N. Sibatulina, I. Kurochkina, SGEM, 5:4, 67 (2017)

4. S. Izmailovich, A. Rahmanov, Proceedings of the 12th International Scientific and Practical Conference, 12, 4 (2019)

5. A. I. Krysovatyy, I. Y. Zvarych, R. Y. Zvarych, M. A. Zhyvko, Comparative Economic Research, 4, 10 (2018)

6. A. Anisimov, D. Motorin, International Journal of Interdisciplinary Environmental Studies, 3-4, 21 (2019)

7. M. S. Dušátková, M. Zinecker, T. Meluzín, Economics \& Sociology, 4, 43 (2017)

8. A. V. Shokhnekh, N. N. Skiter, A. F. Rogachev, T. V. Pleschenko, E. V. Melikhova, Journal of Advanced Research in Law and Economics, 7, 21 (2016)

9. Z. Abdukarimova, K. Bitemirov, N. Bizhan, A. Esenaliyev, N. Poshanov, Z. Kalkanova, Journal of Advanced Research in Law and Economic, 4:34, 65 (2018)

10. C. Braymen, Y.-M. Chang, Z. Luo, Pacific Economic Review, 2, 76 (2016) 